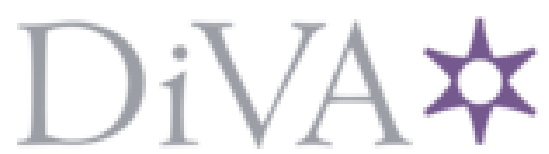

http://www.diva-portal.org

This is the published version of a paper published in Herzogia.

Citation for the original published paper (version of record):

Millanes, A., Diederich, P., Westberg, M., Wedin, M. (2016)

Three new species in the Biatoropsis usnearum complex..

Herzogia, 29: 337-354

Access to the published version may require subscription.

N.B. When citing this work, cite the original published paper.

Permanent link to this version:

http://urn.kb.se/resolve?urn=urn:nbn:se:nrm:diva-2025 


\title{
Three new species in the Biatoropsis usnearum complex
}

\author{
Ana M. Millanes*, Paul Diederich, Martin Westberg \& Mats Wedin
}

\begin{abstract}
Millanes, A. M., Diederich, P., Westberg, M. \& Wedin, M. 2016. Three new species in the Biatoropsis usnearum complex. - Herzogia 29: 337-354.

Three new species of Biatoropsis are formally described based on our previous molecular studies, and on additional molecular, morphological, and ecological data. Biatoropsis protousneae sp. nov. is confined to Protousnea dusenii. Biatoropsis minuta sp. nov. is characterized by the small and brown to black basidiomatal galls, and by growing on Usnea barbata and U. lapponica. Biatoropsis hafellneri sp. nov. is distinguished by 2-celled basidia with cells that elongate laterally at maturity, and by growing on species of the Usnea fragilescens aggregate. A fourth Biatoropsis species is left unnamed, and two other lineages are not described, all waiting for the study of additional material.
\end{abstract}

Zusammenfassung: Millanes, A. M., Diederich, P., Westberg, M. \& Wedin, M. 2016. Drei neue Arten aus dem Biatoropsis usnearum-Komplex. - Herzogia 29: 337-354.

Drei neue Biatoropsis-Arten werden auf Basis unserer früheren molekularen Studien, sowie auf zusätzlichen molekularen, morphologischen und ökologischen Daten beschrieben. Biatoropsis protousneae sp. nov. kommt ausschließlich auf Protousnea dusenii vor. Biatoropsis minuta sp. nov. ist charakterisiert durch kleine, braune bis dunkle BasidiomaGallen und durch das Vorkommen auf Usnea barbata und U. lapponica. Biatoropsis hafellneri sp. nov. unterscheidet sich durch zweizellige Basidien mit Zellen die sich lateral deutlich verlängern, und durch das Vorkommen auf Arten aus dem Usnea fragilescens-Aggregat. Eine vierte Biatoropsis-Art wird nicht formal beschrieben, und zwei weitere Abstammungslinien werden nicht behandelt, da zusätzliches Material untersucht werden sollte.

Kew words: Basidia, galls, host selection, phylogenetics, Protousnea, Tremellales, Tremellomycetes, Usnea.

\section{Introduction}

Lichen-inhabiting fungi are common within the Tremellales (DiEDERICH 1986, 1996, 2003, 2007, Diederich \& Marson 1988, Sérusiaux et al. 2003, Zamora et al. 2011, 2016, Millanes et al. 2012, 2014a, 2015, Diederich et al. 2014, AriyaWANSA et al. 2015). Among them, the monotypic genus Biatoropsis is probably one of the most common and widespread lichenicolous taxa, growing on different hosts of the genera Usnea and Protousnea. Biatoropsis usnearum was first described as an ascomycete by RäsäNEN (1934), but it was later revealed as a basidiomycete with auricularioid basidia (Diederich 1990, Diederich \& CHristiansen 1994). Millanes et al. (2011) confirmed its placement within the Tremellales using molecular methods. As many other taxa in the group, Biatoropsis induces the formation of galls on the host thallus, which, in the case of this genus, show a remarkable variation in morphology. This led Diederich \& Christiansen (1994) to suggest that B. usnearum could in reality represent several species. Millanes et al. (2014b) proved later, based on several lines of evidence and using a multigene approach, the existence of several independently evolving lineages within

* Corresponding author 
the genus. The purpose of this manuscript is to formally describe three new species within the Biatoropsis usnearum species complex, based on a combination of molecular, morphological and ecological data. The presence of additional lineages in the complex, which we refrain from formally describing at this moment, is also discussed.

\section{Material and Methods}

\section{Morphological studies}

Herbarium specimens are deposited in ASU, GZU, H, MA-Fungi, MAF-Lich, O, S, SEY, UBC and UPS, and in the private collections of F. Berger and P. Diederich. External morphology of herbarium specimens was examined and measured using an Olympus SZX16 or a Leica MZ 7.5 dissecting microscope. Macroscopic photographs were either taken using an OlympusDP11 camera on an Olympus SZX16 dissecting microscope, or using a Canon 40D camera with a Canon MP-E 65 macro lens or a Nikon BD Plan 10× microscope objective, StackShot (Cognisys) and Helicon Focus (HeliconSoft) for increasing the depth of field. Microscopical structures were studied using hand-cut sections stained with phloxine (1\% in water) after pretreatment with $\mathrm{KOH}$ (5\%), following the methods of DiEDERICH (1996), and observed with an Olympus CX40 microscope or a Leica DMLB. Drawings were performed by direct observation. Microscopic photographs were prepared using an Olympus BX53 microscope fitted with differential interference contrast (DIC), and an Olympus DP11 camera; or a Leica DMLB microscope with DIC, using a Leica EC3 camera, and Helicon Focus. The apiculus was not included in basidiospore measurements. Basidiospore length/width ratio is expressed as Q. Sizes in parentheses represent minimum and maximum observed values.

\section{Molecular studies}

Choice of additional taxa and outgroup: In addition to 38 Biatoropsis specimens studied in Millanes et al. (2014b), 29 additional specimens were included in the molecular study (Table 1). Tremella cetrariicola was used as outgroup.

DNA extraction and amplification: DNA was extracted directly from the specimens examined (Table 1). Three to ten basidiomata were selected from each specimen for DNA extraction. Total DNA was extracted using the Qiagen DNeasy Plant MiniKit, according to the manufacturer's instructions, but using $50 \mu \mathrm{l}$ of water in each of the last two steps of final elution.

For PCR amplification, the primers ITS1F (GARDES \& BRUNS 1993) and BasidLSU3-3 (Millanes et al. 2011) were used to amplify the internal transcribed spacer I, the 5.8 rDNA gene, the internal transcribed spacer II and a fragment of c. 400 bp in the nuLSU rDNA gene. PCR amplifications were performed using Illustra ${ }^{\mathrm{TM}}$ Hot Start PCR beads, according to the manufacturer's instructions, with the following settings: we used initial denaturing at $95^{\circ} \mathrm{C}$ for $3 \mathrm{~min}$, four cycles $\left(95^{\circ} \mathrm{C}\right.$ for $40 \mathrm{~s}, 53^{\circ} \mathrm{C}$ for $40 \mathrm{~s}$ and $72^{\circ} \mathrm{C}$ for $\left.90 \mathrm{~s}\right)$, four cycles $\left(95^{\circ} \mathrm{C}\right.$ for 30 $\mathrm{s}, 50^{\circ} \mathrm{C}$ for $30 \mathrm{~s}$ and $72^{\circ} \mathrm{C}$ for $90 \mathrm{~s}$ ), and finally 32 cycles $\left(95^{\circ} \mathrm{C}\right.$ for $30 \mathrm{~s}, 47^{\circ} \mathrm{C}$ for $30 \mathrm{~s}$ and $72{ }^{\circ} \mathrm{C}$ for $90 \mathrm{~s}$ ) with a final extension at $72^{\circ} \mathrm{C}$ for $480 \mathrm{~s}$.

The PCR-products were sequenced using the DYEnamic ET terminator cycle sequencing kit (Amersham Biosciences, Freiburg, Germany), with the following settings: 25 cycles $\left(95^{\circ} \mathrm{C}\right.$ for $20 \mathrm{~s}, 50^{\circ} \mathrm{C}$ for $15 \mathrm{~s}$, and $60^{\circ} \mathrm{C}$ for $60 \mathrm{~s}$ ). Post-reaction clean-up was carried out following DYEnamic ET terminator cycle sequencing kit protocols (Amersham Biosciences). The purified samples were run on an automated sequencer (ABI Prism 377) located in the Molecular 
Systematic Laboratory at the Swedish Museum of Natural History, or on an automated sequencer (ABI Prism 3100-Avant) in the Genomic Unit at Rey Juan Carlos University (Madrid).

Sequence alignment and phylogenetic analyses: Sequences were aligned using the Q-INS-i algorithm (КАTOH \& Tон 2008a) of the multiple sequence alignment software MAFFT version 6.611 (КАTOH et al. 2002, КАТOH \& TоH 2008b). Ambiguous regions were identified and eliminated with Gblocks version 0.91b (CASTRESANA 2000). Bayesian analyses were performed by Markov chain Monte Carlo (MCMC) sampling as implemented in the software MrBayes 3.2.4 (RonQuist et al. 2012). We selected the substitution model using the Akaike Information Criterion (AIC) as implemented in jModeltest (GuINDON \& GASCUEL 2003, POSADA 2008). We used full likelihood optimization, six discrete gamma categories, and selected only among the 24 models implemented in MrBayes, and a SYM $+\Gamma$ model was selected. Maximum likelihood analyses were performed in RAxMLGUI 1.3 (SILVESTRO \&MichALAK 2012), a graphical front-end for RAxML (STAMATAKIs 2006), using the GTRGAMMAI model of nucleotide substitution applied to all partitions. We performed a thorough ML search and assessed node support by thorough bootstrap using 1000 bootstrap pseudoreplicates.

\section{Results and Discussion}

We generated 29 new sequences including the ITS and a fragment of ca. $400 \mathrm{pb}$ in the nuLSU. Only the sequenced fragments corresponding to the ITS were used in the alignment, together with ITS sequences already available in GenBank (Table 1). We excluded the fragment corresponding to the nuLSU, because the quality of this portion was not good in some of the newly generated sequences. In this way we produced a homogeneous data matrix, including 408 characters and no missing data. The best tree obtained from the ML analysis had a lnlikelihood value of -2684.4092. The Bayesian analysis halted after 3,700,000 generations, at which time the average standard deviation of split frequencies across runs was 0.0098 , which indicates that the three runs had converged $(<0.01)$. A majority-rule consensus tree was constructed from the 18,500 trees of the stationary tree sample. Since the topologies of the ML and the Bayesian trees were congruent, only the best tree of the ML analysis is shown in Fig. 1.

The phylogenetic analyses recover six monophyletic lineages, coinciding with the clades A2, B, C, D, E and F, already distinguished by Millanes et al. (2014b) (Fig. 1). From these, three new species corresponding to clades A2, B and D, are formally described below (Figs 2-7). Clade F is not formally described, and left unnamed, since we have not been able to study enough material to identify characters, other than molecular data, that allow distinguishing it from other species. However, the main morphological and ecological characteristics observed so far are summarized and discussed also below (Fig. 10). Clade E is based on a single specimen and we refrain from describing this as a species until more material can be studied. In addition, group A1 (Millanes et al. 2014b) is not supported, and was revealed to comprise several lineages, which probably represent several species. Therefore, the taxonomic treatment of group A1 is also postponed until additional available material and sequence data will allow a detailed study and the identification of supported independent evolving lineages. An identification key is therefore not presented at the moment, and will be prepared at a later stage, when it is possible to include the currently undescribed species that belong in the complex. 
Table 1: Sequences newly produced for the present study (bold), or downloaded from GenBank. Type specimens are indicated by $(\mathrm{T})$.

\begin{tabular}{|c|c|c|}
\hline Taxon name-DNA extraction number & Specimen data & ITS \\
\hline Biatoropsis hafellneri-AM299 & Azores, Diederich 17087b (S F264687) & KJ404880 \\
\hline Biatoropsis hafellneri-AM463 & Madeira, Diederich 17788 (hb. Diederich) & KX687722 \\
\hline Biatoropsis hafellneri-AM462 & Madeira, Diederich 17791 (S F291448) & KX687723 \\
\hline Biatoropsis hafellneri-AM461 & Madeira, Diederich 17793 (hb. Diederich) & KX687724 \\
\hline Biatoropsis hafellneri-AM464a & Madeira, Diederich 17796, pale galls (S F291456) & KX687725 \\
\hline Biatoropsis hafellneri-AM464b & Madeira, Diederich 17796, dark galls (S F291456) & KX687726 \\
\hline Biatoropsis hafellneri-AM459 & Madeira, Diederich 17800 (hb. Diederich) & KX687727 \\
\hline Biatoropsis hafellneri-AM398 & Norway, Haugan 7969 (O L157359) & KX687728 \\
\hline Biatoropsis hafellneri-AM216 & UK, 2010, Millanes s.n. (S F291458) & KX687729 \\
\hline Biatoropsis hafellneri-AM110 & UK, Wedin 7306 (S F92121, UPS F766825) & KJ404881 \\
\hline Biatoropsis hafellneri-AA10 (T) & $\begin{array}{l}\text { UK, Wedin } 7308 \text { (UPS F766824 - holotype; GZU, S } \\
\text { F102403 - isotypes) }\end{array}$ & JN053489 \\
\hline Biatoropsis minuta-AM172 & Canada, Diederich 17269. (S F102406, hb. Diederich) & KJ404866 \\
\hline Biatoropsis minuta-AM229 & India, Divakar s.n. (MAF-Lich) & KJ404868 \\
\hline Biatoropsis minuta-AM137 (T) & $\begin{array}{l}\text { Spain, Aragón s.n. (S F102398 - holotype; hb. Diederich, } \\
\text { UPS F766826 - isotypes) }\end{array}$ & KJ404869 \\
\hline Biatoropsis minuta-AM168 & Spain, Burgaz \& Martinez s.n. (MA-Fungi 48236) & KJ404870 \\
\hline Biatoropsis minuta-AM212 & Spain, Merinero s.n. (S F264683) & KJ404871 \\
\hline Biatoropsis minuta-AA9 & Sweden, Hagner s.n. (S F92134, (UPS F766831) & JN053486 \\
\hline Biatoropsis minuta-AM155 & Sweden, Hagner s.n. (UPS 355785) & KJ404867 \\
\hline Biatoropsis minuta-CO294 & Sweden, Wedin 7903 (S F102401, UPS F766830) & JN053487 \\
\hline Biatoropsis minuta-AM635 & Sweden, 2015, Westberg s.n. (S F291459) & KX687730 \\
\hline Biatoropsis protousneae-AM215 & Argentina, Wedin 8601 (S F264822) & KJ404861 \\
\hline Biatoropsis protousneae-AM214 & Argentina, Wedin 8615 (S F264823) & KJ404865 \\
\hline Biatoropsis protousneae-AM139 (T) & $\begin{array}{l}\text { Chile, Pérez-Ortega } 207 \text { (S F291460 - holotype; hb. } \\
\text { Diederich - isotype) }\end{array}$ & KJ404862 \\
\hline Biatoropsis protousneae-AM138 (T) & Chile, Pérez-Ortega 207 (MAF-Lich - isotype) & KJ404863 \\
\hline Biatoropsis protousneae-AM142 (T) & Chile, Pérez-Ortega 207 (MAF-Lich - isotype) & KJ404864 \\
\hline Biatoropsis protousneae-AM141 & Chile, Pérez-Ortega 216 (MAF-Lich) & KJ404860 \\
\hline Biatoropsis usnearum-AM196 & Austria, Hafellner 49578 (GZU 02-99) & KJ404878 \\
\hline Biatoropsis usnearum-AM297 & Azores, Diederich 17058 (S F264685) & KJ404873 \\
\hline Biatoropsis usnearum-AM298 & Azores, Diederich 17087a (S F264684) & KJ404872 \\
\hline Biatoropsis usnearum-AM631 & Canada, 2006, Goward s.n, pale galls (UBC) & KX687731 \\
\hline Biatoropsis usnearum-AM632 & Canada, 2006, Goward s.n, brown galls (UBC) & KX687732 \\
\hline Biatoropsis usnearum-AM629 & Canada, 2008, Goward s.n. (UBC) & KX687733 \\
\hline Biatoropsis usnearum-AM630 & Canada, Björk 14689 (UBC) & KX687734 \\
\hline Biatoropsis usnearum-AM211 & Canary islands, Amo de Paz s.n. (MAF-Lich) & KJ404874 \\
\hline Biatoropsis usnearum-AM478 & Madeira, Diederich 17778 (hb. Diederich) & KX687735 \\
\hline Biatoropsis usnearum-AM465 & Madeira, Diederich 17792 (hb. Diederich) & KX687736 \\
\hline Biatoropsis usnearum-AM460 & Madeira, Diederich 17794 (S F291461) & KX687737 \\
\hline Biatoropsis usnearum-AM201 & Sweden, Westberg 09-674 (S F264680) & KJ404877 \\
\hline Biatoropsis usnearum-AM203 & Sweden, Westberg 09-675 (S F264682) & KJ404875 \\
\hline Biatoropsis usnearum-AM202 & Sweden, Westberg 09-676 (S F264681) & KJ404876 \\
\hline Biatoropsis usnearum-AM171 & UK, Coppins s.n. (S F102407) & KJ404879 \\
\hline Biatoropsis usnearum-AM218 & UK, Millanes 507 (S F291462) & KX687738 \\
\hline Biatoropsis usnearum-AM222 & UK, 2010, Westberg s.n. (S F291463) & KX687739 \\
\hline
\end{tabular}




\begin{tabular}{|l|l|c|}
\hline Taxon name-DNA extraction number & Specimen data & ITS \\
\hline Biatoropsis sp. A1-AM112 & Canary Islands, Diederich 16700 (S F102402) & KJ404856 \\
\hline Biatoropsis sp. A1-AM191 & Chile, Etayo 22655 (MAF-Lich 15628) & KJ404852 \\
\hline Biatoropsis sp. A1-AM192 & Chile, Etayo 23158 (MAF-Lich 15645) & KJ404851 \\
\hline Biatoropsis sp. A1-AM190 & Chile, Etayo 24529 (MAF-Lich) & KJ404853 \\
\hline Biatoropsis sp. A1-AM140 & Chile, Pérez-Ortega 215 (MAF-Lich) & KJ404855 \\
\hline Biatoropsis sp. A1-AM471 & Madeira, Diederich 17770 (hb. Diederich) & KX687740 \\
\hline Biatoropsis sp. A1-AM479 & Madeira, Diederich 17772 (hb. Diederich) & KX687741 \\
\hline Biatoropsis sp. A1-AM458a & Madeira, Diederich 17773 (S F291464) & KX687742 \\
\hline Biatoropsis sp. A1-AM476 & Madeira, Diederich 17774 (hb. Diederich) & KX687743 \\
\hline Biatoropsis sp. A1-AM477 & Madeira, Diederich 17779 (hb. Diederich) & KX687744 \\
\hline Biatoropsis sp. A1-AM475 & Madeira, Diederich 17780 (hb. Diederich) & KX687745 \\
\hline Biatoropsis sp. A1-AM473 & Madeira, Diederich 17782 (S F291457) & KX687746 \\
\hline Biatoropsis sp. A1-AM470 & Madeira, Diederich 17797 (hb. Diederich) & KX687747 \\
\hline Biatoropsis sp. A1-AM307 & New Zealand, Myles s.n. (S F186043) & KJ404859 \\
\hline Biatoropsis sp. A1-AM296 & New Zealand, Wedin 9033 (S F180874) & KJ404854 \\
\hline Biatoropsis sp. A1-AM143 & Spain, Pérez-Ortega s.n. a (MAF-Lich) & KJ404857 \\
\hline Biatoropsis sp. A1-AM144 & Spain, Pérez-Ortega s.n. b (MAF-Lich) & KJ404858 \\
\hline Biatoropsis sp. A1-AM217 & UK, Millanes 574 (S F291465) & KX687748 \\
\hline Biatoropsis sp. E-AM213 & Argentina, Wedin 8742 (S F264824) & KJ404882 \\
\hline Biatoropsis sp. F-AM567 & France, Diederich 18149 (hb. Diederich) & KX687749 \\
\hline Biatoropsis sp. F-AM10 & New Zealand, Berger 16609 (S F92784) & KJ404884 \\
\hline Biatoropsis sp. F-295 & New Zealand, Wedin 9429 (S F181399) & KJ404883 \\
\hline Biatoropsis sp. F-AM576 & Seychelles, Diederich 18087 (S, SEY, hb. Diederich) & KX687750 \\
\hline Biatoropsis sp. F-AM166 & USA, Kocourková s.n. (S F264679) & KJ404885 \\
\hline Tremella cetrariicola AM111 & Finland, Suija s.n. (S F102413) & JN053490 \\
\hline
\end{tabular}

\section{The species}

Biatoropsis hafellneri Millanes, Diederich, M.Westb. \& Wedin sp. nov. [MycoBank 817903] (Figs 2-3)

Type: United Kingdom, Cornwall, Lamorna Cove, Lamorna Valley, $50^{\circ} 03^{\prime} \mathrm{N}, 05^{\circ} 32^{\prime} \mathrm{E}$, on Usnea cornuta, 11.IV.2004, M. Wedin 7308 (holotype: UPS F766824; isotypes: GZU and S F102403).

Etymology: It is with great pleasure that we dedicate the new species to Prof. Josef Hafellner (Austria), in recognition and gratitude to his contributions to lichenology in general, and to the study of lichenicolous fungi in particular.

Description: Basidiomata inducing the formation of galls that are initially regularly convex to subglobose, later constricted at the base, sometimes with a central depression and/or tuberculate when mature, very pale to orangish, occasionally brown, waxy gelatinous when wet $0.1-1.3 \mathrm{~mm}$ diam. Galls often developing on broken fibrils. Context hyphae thin-walled, $2-3 \mu \mathrm{m}$ diam., clamp connections occasionally present. Haustorial branches frequent, mother cell spherical to subspherical, (2-)3-4 × 3-4(-5) $\mu \mathrm{m}$, haustorial filament $1 \mu \mathrm{m}$ diam., up to $5 \mu \mathrm{m}$ long. Hymenium hyaline, containing numerous probasidia, probasidial initials clavate, often developing from a basal clamp, which is not observed in mature basidia. Basidia, when mature, 2-celled (exceptionally 3-celled), with one transverse septum 20-46 $\times 4-8 \mu \mathrm{m}$, the two cells laterally much elongate at maturity, sometimes giving the appearance of two immature independent basidia, individual basidial cells up to $40 \mu \mathrm{m}$ long, $4-8 \mu \mathrm{m}$ wide. Basidiospores globose to subglobose, $5-8.5 \times 5-9 \mu \mathrm{m}, \mathrm{Q}=0.7-1$, with a distinct apiculus, $\mathrm{c}$. $1 \mu \mathrm{m}$ diam. Conidia catenulate, hyaline, individual cells $3-8 \times 3-5 \mu \mathrm{m}$.

Ecology and host: The species grows on the thallus of species of the Usnea fragilescens aggregate (CLERC 1987), most frequently on $U$. cornuta. It occurs in oceanic and humid forests where the hosts are present, usually on trees but also on acidic rocks. 


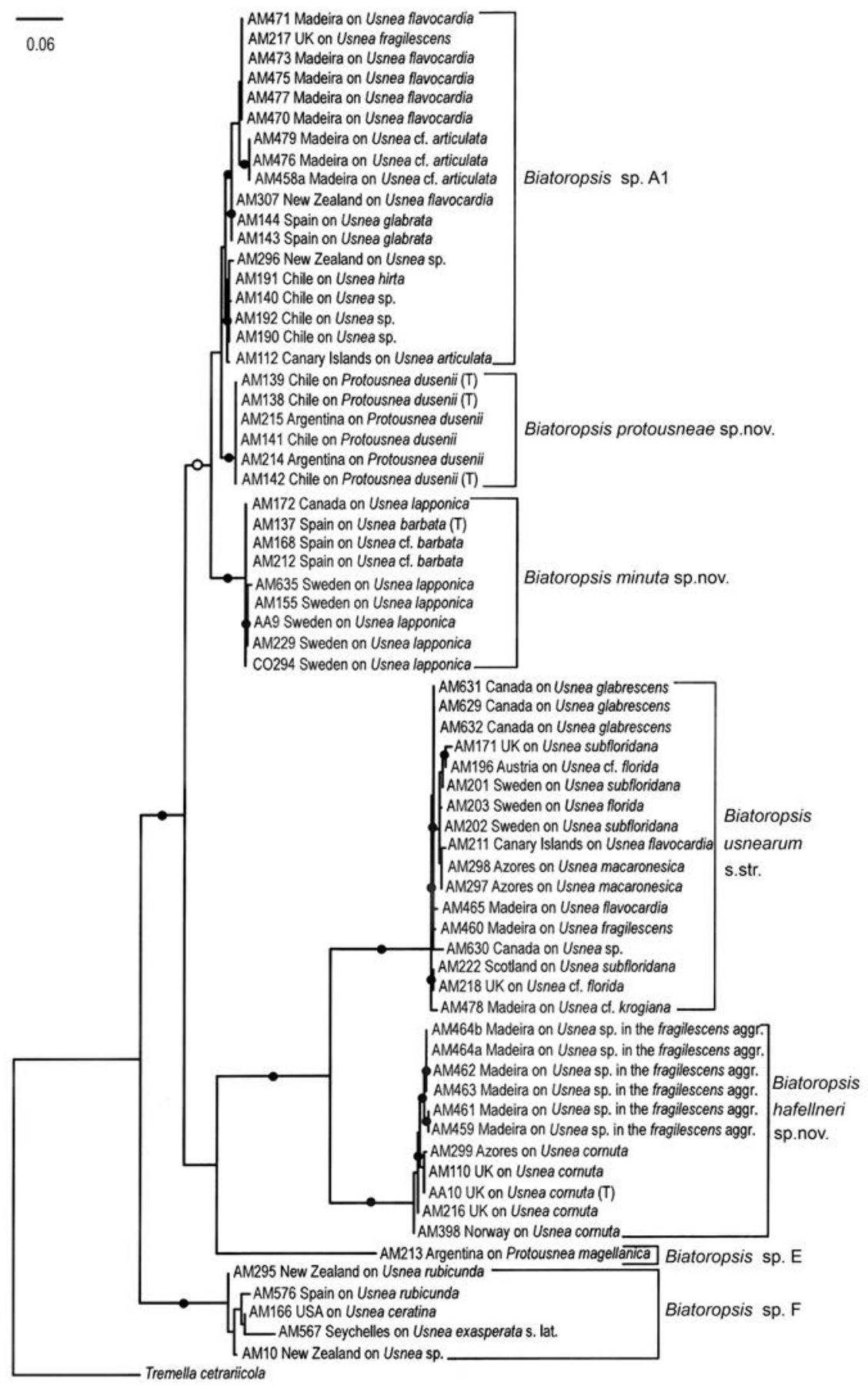

Fig. 1: Phylogram based on ITS sequences, corresponding to the best tree recovered in the maximum likelihood analysis (implemented in RAxMLGUI 1.3), with information on the Bayesian posterior probability values added. Black dots indicate nodes supported both by ML and Bayesian analyses. A white dot indicates a node supported only in the Bayesian analyses. Type specimens are indicated by (T). 
Distribution: Known from the Azores, the Canary Islands, France, Madeira, Norway, Spain, and the U.K.

Notes: Biatoropsis hafellneri corresponds to lineage D distinguished by MiLlanes et al. (2014b) using multigene analyses, and recovered also in this study (Fig. 1). This is the only Biatoropsis species known so far with a very characteristic basidium morphology, consisting of two cells that elongate laterally before the formation of epibasidia. Similar basidia are found in Tremella christiansenii, $T$. diederichiana and T. hypocenomycis, although none of these species grow on Usnea. Tremella christiansenii differs also from the new species in the darker basidiomata, and the size of basidia and basidiospores. Tremella diederichiana has 2- or 4-celled basidia with longitudinal septa, and much bigger basidiospores. The basidiomata of Tremella hypocenomycis are blackish, do not induce the formation of galls, and this species has smaller basidia and basidiospores. Biatoropsis hafellneri is closely related to Biatoropsis usnearum (Fig. 1) from which it is clearly distinguished by the basidium morphology (four celled basidia in B. usnearum) and the host selection. Moreover, although it is not constant in all samples studied, the basidiomata of $B$. hafellneri have a marked tendency to develop on decorticated areas remaining after fibrils of the host have broken (Fig. 3C-D), the galls induced are usually smaller, and its inner part appears to be formed by white host hyphae only.

Additional specimens examined (all on species of the Usnea fragilescens aggregate): Azores. Pico, between Lajes do Pico and Sao Roque do Pico, Bosque da Junqueira, 38²7.93'N, 28¹7.95'W, on U. cornuta, 26.VII.2010, P. Diederich 17087b (S F264687, hb. Diederich). - Canary Islands. Tenerife, Monte Aguirre, on U. cornuta,

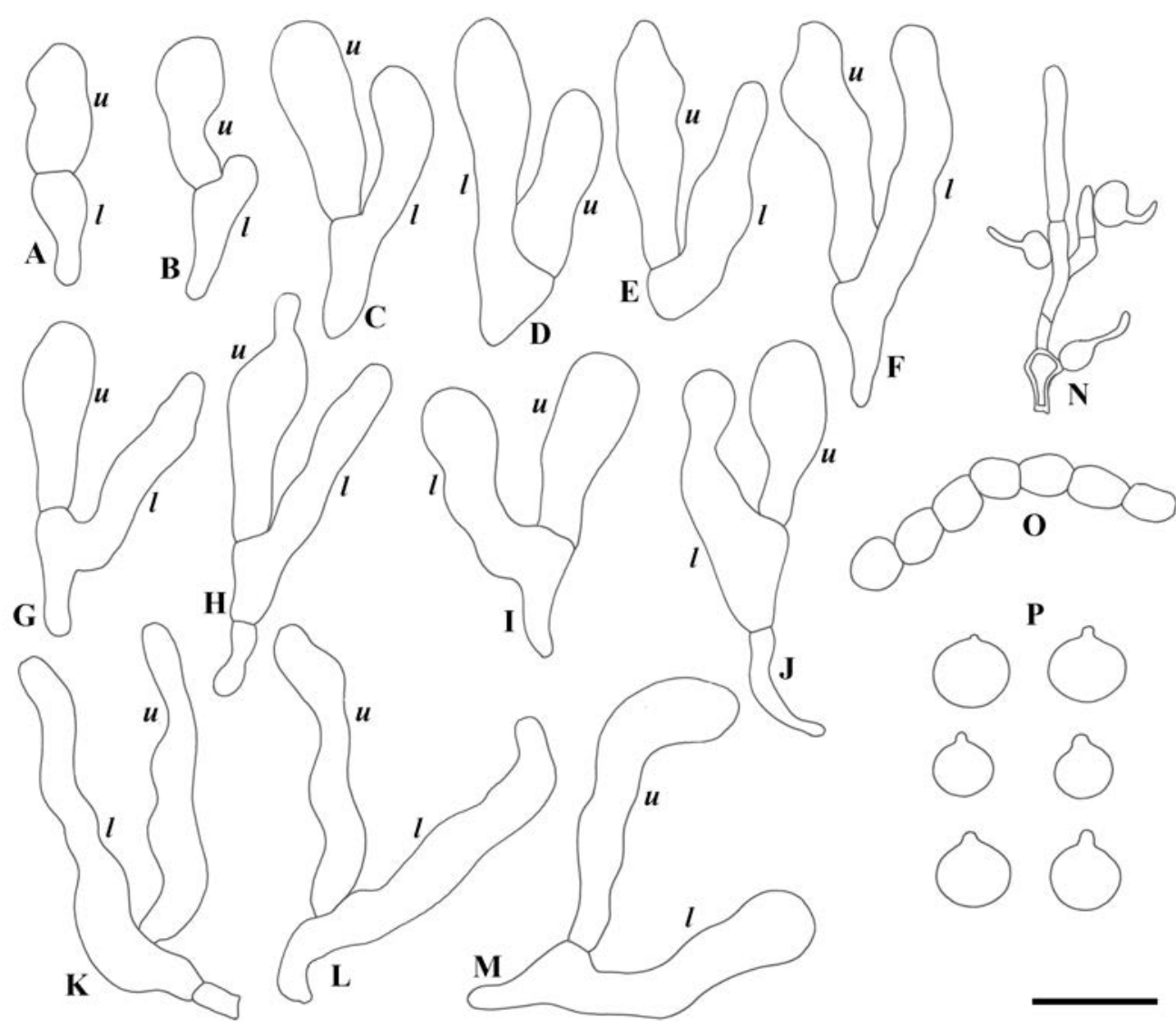

Fig. 2: Biatoropsis hafellneri. A-M - Development of basidia (l: lower and u: upper cell of basidium). $\mathbf{N}-$ Hyphae with haustorial branches. $\mathbf{O}$ - Catenulate conidia. $\mathbf{P}$ - Basidiospores. [All based on type material]. - Scale $=10 \mu \mathrm{m}$. 

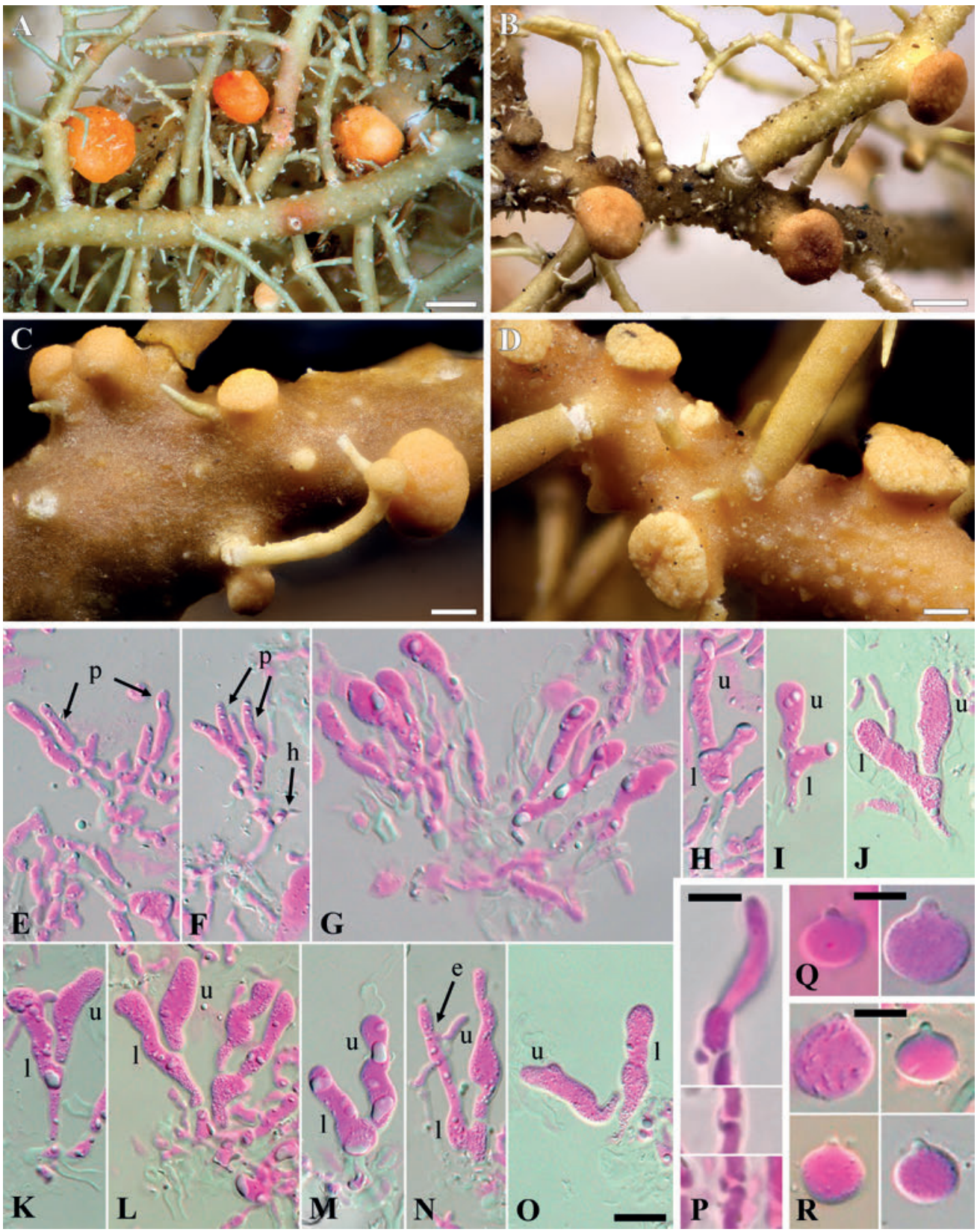

Fig. 3: Biatoropsis hafellneri. A-B - Basidiomata on the thallus of Usnea cornuta. C-D - Young basidiomata developing from broken fibrils of the host (on $U$. sp. in the $U$. fragilescens aggregate). E-O - Development of basidia (p: probasidia; l: lower and u: upper cell of mature basidium). $\mathbf{P}$ - Probasidia with basal clamps. Q-R - Basidiospores. [A, E, H, Q: Wedin 7308 (holotype); B: Diederich 17087b; C, P: Diederich 14614; D: Diederich 4854; F, N, R: Diederich 17800, G: Wedin 7306; I-M, O: Diederich 17788]. - Scales: A-B = $500 \mu \mathrm{m}$; C-D = $200 \mu \mathrm{m} ; \mathrm{E}-\mathrm{O}=10 \mu \mathrm{m}$; $\mathrm{P}-\mathrm{R}=5 \mu \mathrm{m}$. 
1990, U. Becker (hb. Diederich). - France. Finistère, à l’E du Faou, forêt de Cranou, on U. cornuta, 18.VII.2000, P. Diederich 14614 (hb. Diederich). - Madeira. S of Santana, Queimadas, 7.IV.1992, P. Diederich 4854 (hb.

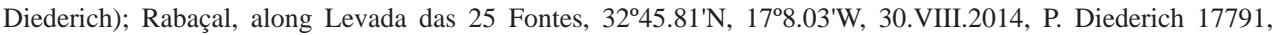
17796 (S F291448, F291456), 17788, 17793, 17796 (S, hb. Diederich); S of São Vicente, 500 m N of Encumeada, 32 $45.48^{\prime}$ N, $17^{\circ} 1.13 W, 27 . V I I I .2014$, P. Diederich 17800 (hb. Diederich). - Norway. Hordaland, Bjørnnåsen, $60^{\circ} 08.32$ 'N, 5²6.40'E, on U. cornuta, 22.V.2008, R. Haugan 7969 (O L157359). - Spain. Navarra, 50 km N of Pamplona, Oronoz-Mugaire, Señorío de Bértiz, on U. cornuta, 22.VII.1991, P. Diederich 9738 (hb. Diederich). U.K. Lamorna Cove, Lamorna Valley, 5003'N, 5³2'E, on U. cornuta, 11.IV.2004, M. Wedin 7306 (S F92121, UPS F766825); Devon, Dartmoore National Park, South Brent, Shipley Bridge, 50²7.06'N, 351.64'W, 25.VIII.2010, A. Millanes s.n. (S - F291458).

Biatoropsis minuta Millanes, Diederich, M.Westb. \& Wedin sp. nov. [MycoBank 817904]

(Figs 4-5)

Type: SPAIN, Palencia, Piedrasluengas, Piedrasluengas mountain pass, $43^{\circ} 2.95^{\prime} \mathrm{N}, 4^{\circ} 27.19^{\prime} \mathrm{W}$, on Usnea barbata, 5.IV.2010, G. Aragón s.n. (holotype: S F102398; isotypes: UPS F766826 and hb. Diederich).

Etymology: In reference to the size of the induced galls, always smaller than $1 \mathrm{~mm}$.

Description: Basidiomata inducing the formation of convex, basally constricted galls, sometimes with a central depression when mature, waxy gelatinous when wet, brown to dark brown or black, 0.1-0.8 mm diam. Context hyphae thin-walled, 2-3 $\mu \mathrm{m}$ diam., clamp connections not observed. Haustorial branches frequent, mother cell spherical to subspherical, (2-)3-4 × 3-4 $\mu$ m, haustorial filament $1 \mu \mathrm{m}$ diam., up to $15 \mu \mathrm{m}$ long. Hymenium hyaline, containing numerous probasidia; proba-
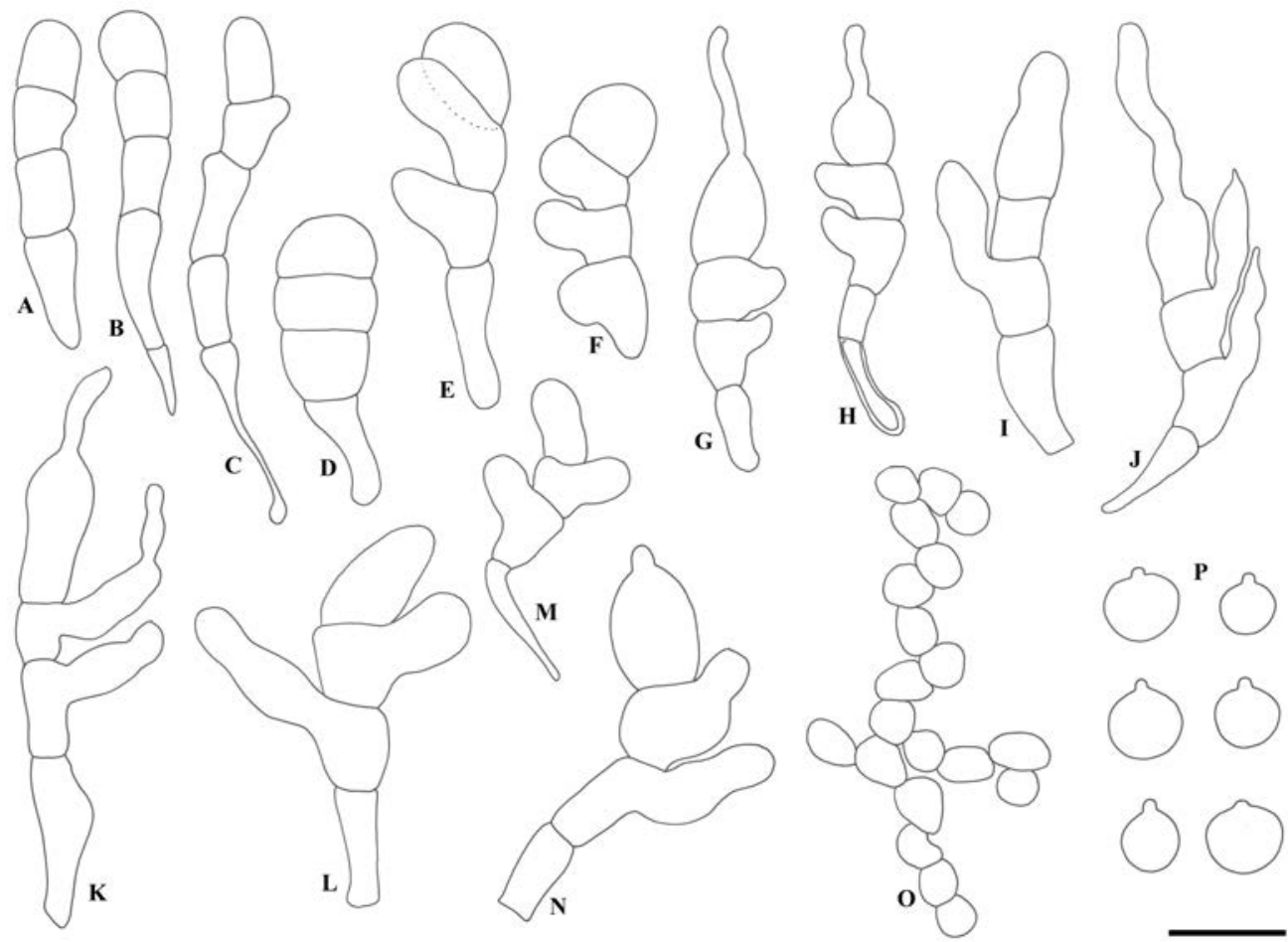

Fig. 4: Biatoropsis minuta. A-N - Development of basidia. $\mathbf{O}$ - Catenulate conidia. $\mathbf{P}$ - Basidiospores [All based on type material]. - Scale $=10 \mu \mathrm{m}$. 

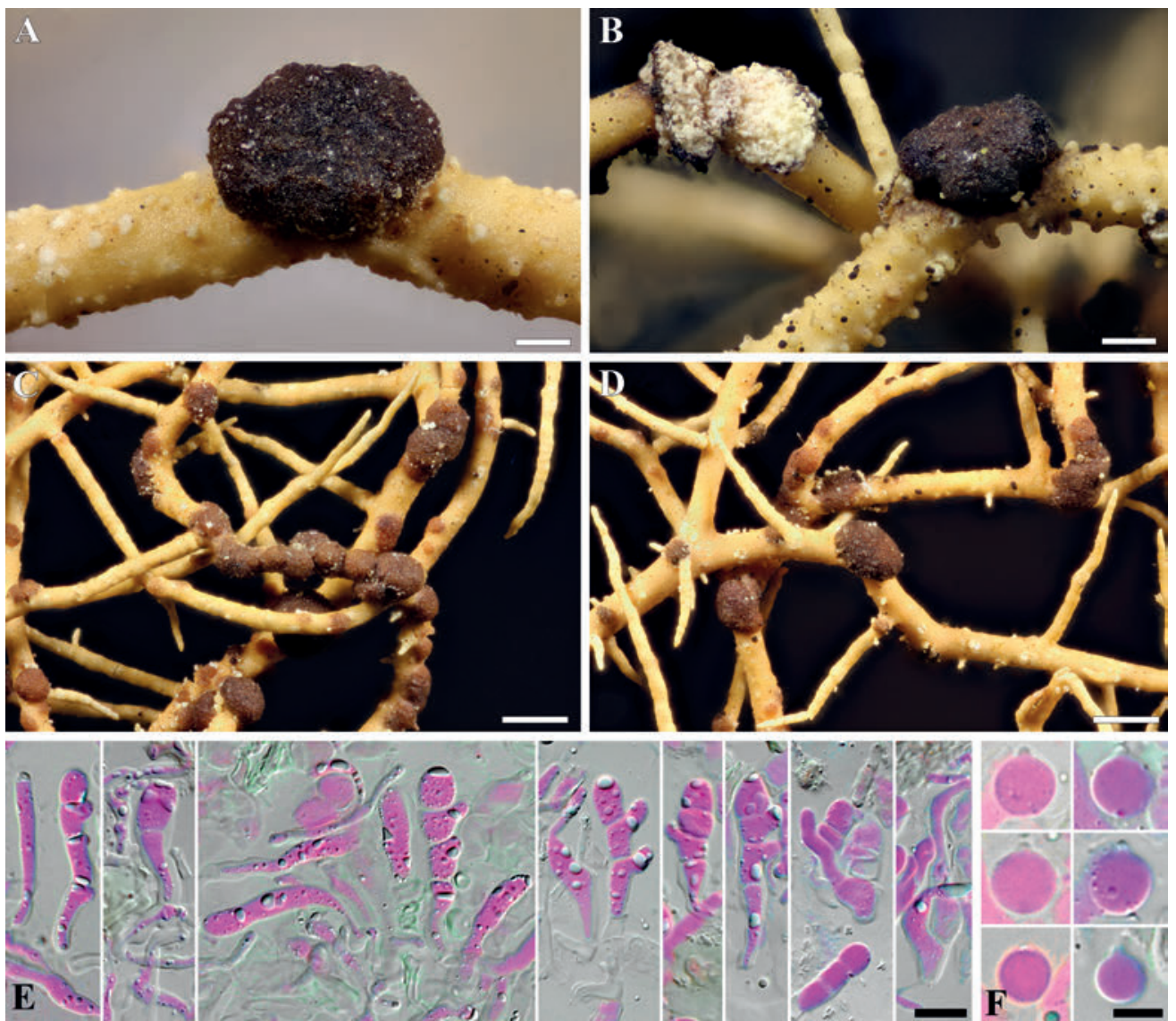

Fig. 5: Biatoropsis minuta. A-D - Basidiomata on the thallus of Usnea lapponica. E - Basidia. F - Basidiospores. [A, E-F: Aragón s.n. (holotype); B: Goward 91-16; C-D: Goward 91-13]. - Scales: A-B = $200 \mu m$; C-D = 500 $\mu \mathrm{m}$; $\mathrm{E}=10 \mu \mathrm{m} ; \mathrm{F}=5 \mu \mathrm{m}$.

sidial initials clavate, proliferations occurring from a basal hypha. Basidia, when mature, 4-celled, with three transverse septa, often constricted at the septa, the lower cell with an attenuated stalk-like base, often longer than the upper cells, 20-46 (-50) × 4-10 $\mu \mathrm{m}$ (incl. stalk-like base, excl. epibasidia), lower part of the stalk-like base $2-4 \mu \mathrm{m}$ diam. Basidiospores globose to subglobose, $5-9.5 \times 5-8 \mu \mathrm{m}$, $\mathrm{Q}=0.83-1.3$, with a distinct apiculus, c. $1 \mu \mathrm{m}$ diam. Conidia catenulate, hyaline, individual cells $2-6 \times 2-4 \mu \mathrm{m}$.

Ecology and hosts: Known only from two closely related species of Usnea, U. barbata and U. lapponica (thallus).

Distribution: Known from Canada, India, Spain, Sweden, Norway, and the U.S.A.

Notes: Biatoropsis minuta corresponds to clade 'B' distinguished by MiLlanes et al. (2014b), and obtained also in this study (Fig. 1). The phylogenetic position of this clade within the whole Biatoropsis usnearum complex is not supported, although the topology recovered place the new species closely related to B. protousneae and group 'A1', and not closely related to other Biatoropsis species. It is a very widespread taxon, clearly distinguished from other known Biatoropsis species by the morphology of the induced galls, which are always smaller than $1 \mathrm{~mm}$ and constantly brown or dark. This colour is due to inner pigments, and not to the presence of hyperparasites intermixed with Biatoropsis. There 
are, to our knowledge, no clear micro-morphological features that could serve to characterize this species, as the microscopical characters are undistinguishable from those of other Biatoropsis species, except B. hafellneri.

Additional specimens examined (all on Usnea lapponica, unless otherwise specified): Canada. British Columbia, Edgewood Blue, $26 \mathrm{~km}$ N of Clearwater on Wells Gray Rd., 51 ${ }^{\circ} 45^{\prime} \mathrm{N}, 120^{\circ} 02^{\prime} \mathrm{W}, 9 . \mathrm{II} .1991$, T. Goward 91-13, 91-16 (UBC, hb. Diederich); Wells Gray Provincial Park, Clearwater valley, 26 km N of Clearwater, near Kingfishers Wood Cottages, 22.VII.2008, P. Diederich 17269 (S F102406, hb. Diederich). - India. Uttaranchal [=Uttarakhand], Joshimath, Nanda Devi National Park, $10 \mathrm{~km}$ before Gamshali, on the way to Niti, $30^{\circ} 42.66^{\prime} \mathrm{N}$, 7950.62'E, 20.VIII.2007, P. Divakar s.n. (MAF-Lich). - Norway. Buskerud, Todalen, E side of Rudåsen, 17.IX.2000, G. Gundersen, H. Gundersen, T.H. Hofton, B.P. Løfall, E. Timdal LL111/14 (O L55896). Hedmark,

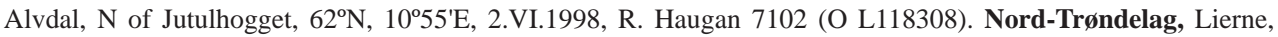
Storåa, west of Gambrennseteren, 9.IX.2009, J.T. Klepsland JK09-L570 (O L165113). Østfold, Marker, Måstadsetra, 18.II.2000, B.P. Løfall bpl-L6558 (O L77293). Sogn of Fjordane, Urnes, 12.VI.1976, R. Bryhn (O); c. 500 m S of Lisete 13.VI.1976, H. østhagen 3540 (O). - Spain. Lleida, Montellà i Martinet, Serra del Cadí, on the way to Prat d'Aguiló, on U. cf. barbata, $42^{\circ} 19.68^{\prime} \mathrm{N}, 1^{\circ} 42.09^{\prime} E$, 2.VII.1996, A.R. Burgaz \& I. Martínez s.n. (MA-Fungi 48236); Madrid, Montejo de la Sierra, on U. cf. barbata, 2010, S. Merinero s.n. (S F264683). - Sweden. Jämtland, Alanäs par., Lidsjöberg, Prästberget, 28.III.2002, Å. Hagner s.n., (S F92134, UPS 766831); Alanäs par., Lidsjöberg, close to the village at Hembäcken 30.XII.2003, Å. Hagner s.n., (UPS L160312); Stugun par., Nybodberget, $63^{\circ} 9.54$ 'N, 1545.31'E, 12.IX.2015, M. Westberg s.n. (S-F291459). Lule Lappmark: Jokkmok par., Lilla Luleäven river,

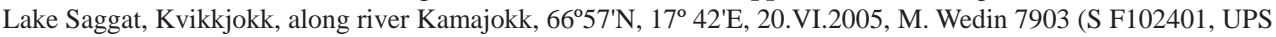
F766830). - U.S.A. Arizona, Coconino Co., Grand Canyon National Park, North Rim, 6 km from State Highway 67 on the road to Cape Royal, $36^{\circ} 15^{\prime} \mathrm{N}, 112^{\circ} 01^{\prime} \mathrm{W}, 3$. VIII.1991, M. Boykin 2410 (ASU).

Biatoropsis protousneae Millanes, Diederich, M.Westb. \& Wedin sp. nov. [MycoBank 817905]

(Figs 6-7)

Type: Chile, XII Region of Magallanes and Chilean Antarctica, Puerto Natales, along the road to Lake Balmaceda, 51 ${ }^{\circ} 56.48^{\prime}$ S, $72^{\circ} 23.28^{\prime} \mathrm{W}$, on Protousnea dusenii, 14.I.2008, S. Pérez-Ortega 207 (holotype: S F291460; isotypes: MAF-Lich and hb. Diederich).

Etymology: In reference to the host, Protousnea dusenii.

Description: Basidiomata inducing the formation of convex, basally constricted galls, tuberculate and often with a central depression when mature, waxy gelatinous when wet, pale to light brown, dark brown, or black, $0.1-2.4 \mathrm{~mm}$ diam. Context hyphae thin-walled, $2-3 \mu \mathrm{m}$ diam., clamp connections not observed. Haustorial branches frequent, mother cell spherical to subspherical, $3-4 \times 3-5 \mu \mathrm{m}$, haustorial filament $1 \mu \mathrm{m}$ diam., up to $14 \mu \mathrm{m}$ long. Hymenium hyaline, containing numerous probasidia, probasidial initials clavate, proliferations occurring from a basal hypha. Basidia, when mature, 4-celled, with three transverse septa, often constricted at the septa, the lower cell with an attenuated stalk-like base, often longer than the upper cells, 22-60 × 4-10 $\mu \mathrm{m}$ (incl. stalk-like base, excl. epibasidia), lower part of the stalk-like base $2-4 \mu \mathrm{m}$ diam., epibasidia frequent, $2-4 \mu \mathrm{m}$ wide, up to $45 \mu \mathrm{m}$ long. Basidiospores globose to subglobose, $5-8 \times 5-9 \mu \mathrm{m}, \mathrm{Q}=0.7-1.3$, with a distinct apiculus, c. $1 \mu \mathrm{m}$ diam. Conidia catenulate, hyaline, individual cells $3-7 \times 3-6 \mu \mathrm{m}$.

Ecology and host: Lichenicolous on Protousnea dusenii (thallus).

Distribution: Known from Argentina and Chile.

Notes: This species corresponds to clade A2 distinguished by MiLlanes et al. (2014b) using multigene analyses, and obtained also in this study (Fig 1). The species is micro- and macromorphologically similar to samples belonging to group A1, to which it is phylogenetically closely related. Biatoropsis protousneae is, however, distinguished from that taxon by its host selection. The species can also be confused with Biatoropsis usnearum s. str. except for the distinct host. The brown colour of the basidiomata of $B$. protousneae seems to be due to inner pigments, and not to the presence of hyperparasites, as it is often the case in $B$. usnearum. However, these two circumstances (presence or absence of hyperparasites in brown galls) have been observed in both species and the character is therefore not suitable for distinguishing them. Orange galls have not been found in B. protousneae.

Additional specimens examined (all on Protousnea dusenii): Argentina. Río Negro, Nahuel Huapi National Park, ca. $13 \mathrm{~km}$ S Bariloche, along the road to Refugio Neumeyer, $41^{\circ} 15.48^{\prime} \mathrm{S}, 7^{\circ} 17.16^{\prime} \mathrm{W}, 14 . I I .2010$, M. Wedin 8601 


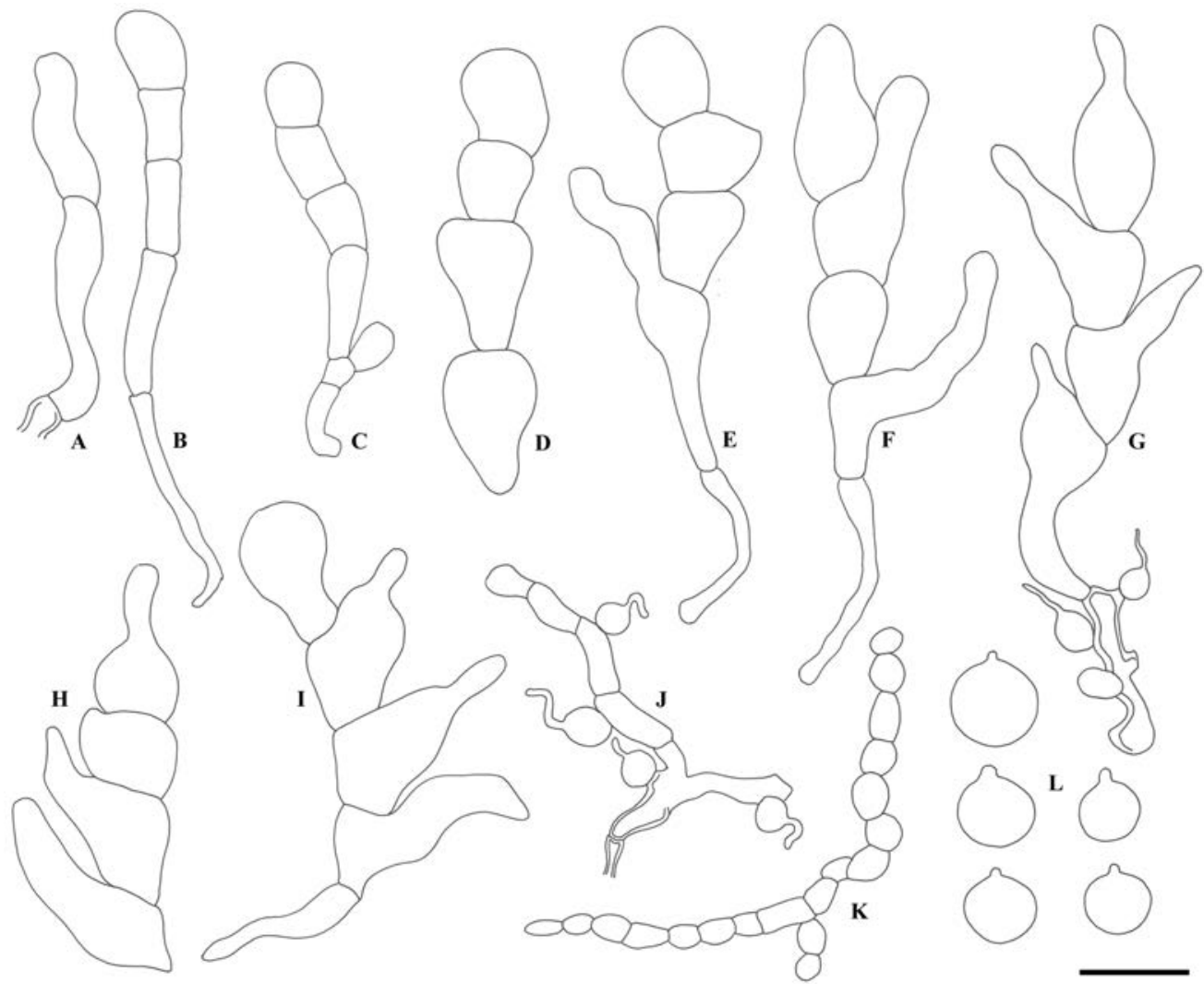

Fig. 6: Biatoropsis protousneae. A-I - Development of basidia. J - Hyphae with haustorial branches. K - Catenulate conidia. $\mathbf{L}$ - Basidiospores. [All based on type material]. - Scale $=10 \mu \mathrm{m}$.

(S F264822); Parque Nacional Nahuel Huapi, c. 5 km W Bariloche, Cerro Otto, 41º8.68'S, 71²2.1'W, 19.II.2010, M. Wedin 8615 (S F264823). - Chile. XII Region of Magallanes and Chilean Antarctica, Isla Navarino, Puerto Williams, Cerro Bandera, 550.08'S, 67²41.53'W, 19.I.2008, S. Pérez-Ortega 216 (MAF-Lich).

Biatoropsis usnearum Räsänen s.str. [MycoBank 281203]

(Figs 8-9)

Ann. bot. Soc. Zool.-bot. fenn. 'Vanamo’ 5(9): 8 (1934)

Type: Finland, Ostrobottnia borealis, Simo Kuusella, on 'Usnea comosa', 1.VII.1915, V. Räsänen (lectotype: H[!]; isotype: IMI, fide Hawksworth).

Description: Basidiomata extremely variable in form, size and colour, generally subspherical and convex with a constricted base, often with lobate margins, sometimes flattened or with a concave central part, rarely effuse and covering larger areas around the branches of the host, surface smooth, rarely tuberculate, cartilaginous, pale pinkish, reddish brown, dark brown or black, $0.2-3 \mathrm{~mm}$ diam. Context hyphae $2-3 \mu \mathrm{m}$ wide, mostly uniform, walls not markedly thickened, clamps not observed. Haustorial branches frequent, mother cell subspherical or sometimes elongate, $2.5-5 \mu \mathrm{m}$ diam., haustorial filament $0.5-1 \mu \mathrm{m}$ thick, up to $11 \mu \mathrm{m}$ long. Hymenium containing numerous probasidia, developing from a basal clamp that is not observed in mature basidia. Basidia, when mature, clavate to subcylindrical, 4-celled, with 3 transverse septa, $20-44 \times 3-6.5 \mu \mathrm{m}$, epibasidia 2-3 $\mu \mathrm{m}$ thick, up to $85 \mu \mathrm{m}$ long. Basidiospores subglobose to ellipsoid, $4.5-8 \times 4-7.5 \mu \mathrm{m}$, with a distinct apiculus.

Conidia catenulate, hyaline, individual cells $3-5 \times 2-3.5 \mu \mathrm{m}$. 

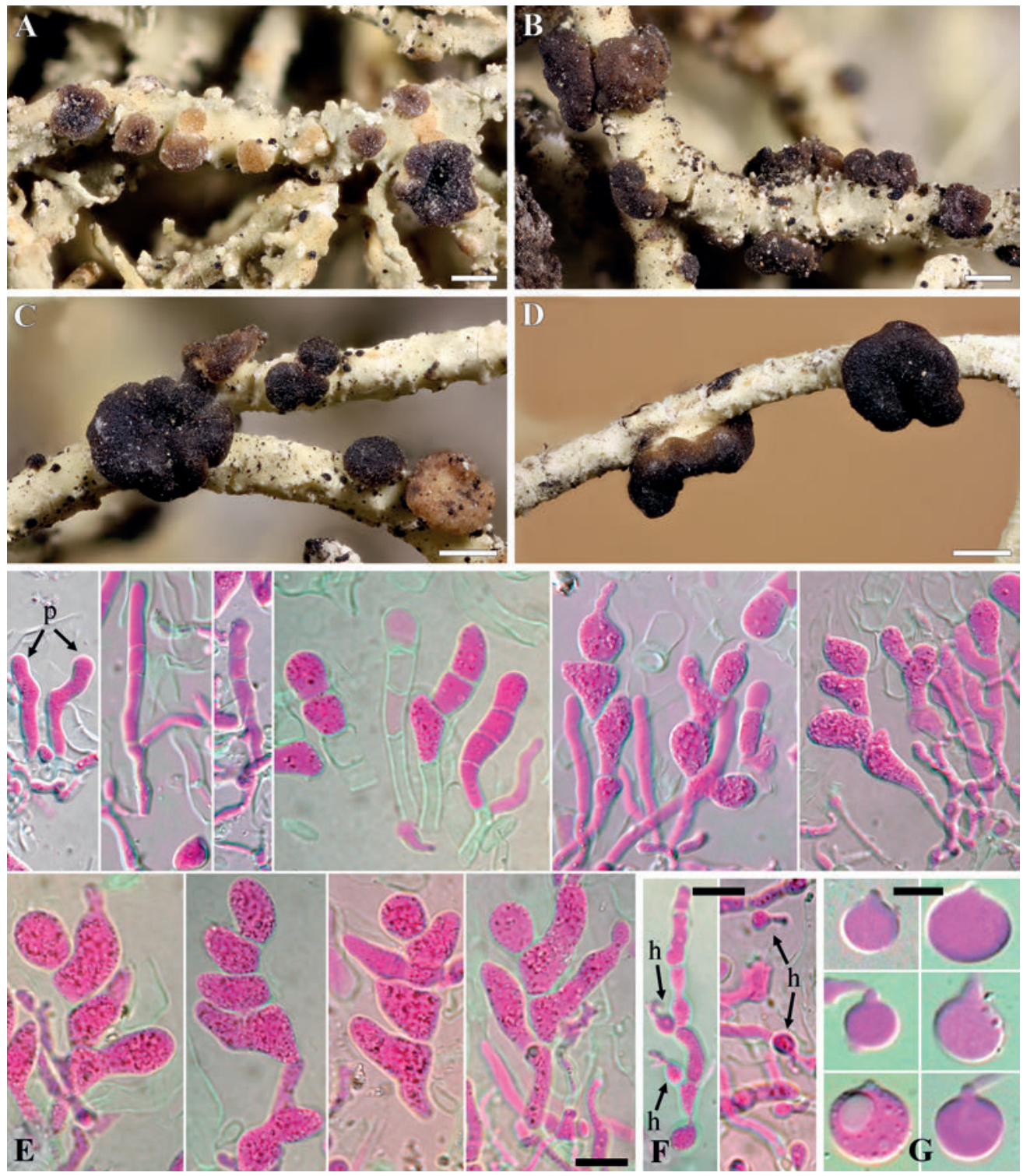

Fig. 7: Biatoropsis protousneae. A-D - Basidiomata on the thallus of Protousnea dusenii. E - Probasidia (p) and mature basidia. F - Haustorial branches (h). G - Basidiospores. [All based on type material]. - Scales: A-D = 500 $\mu \mathrm{m}$; $\mathrm{E}-\mathrm{F}=10 \mu \mathrm{m} ; \mathrm{G}=5 \mu \mathrm{m}$.

Ecology and hosts: Lichenicolous on the thallus of Usnea hosts (neither on Protousnea nor on the subgenus Neuropogon), including U. flavocardia, U. florida/subfloridana, U. fragilescens, U. glabrescens, $U$. cf. krogiana and U. macaronesica. The European specimens (excluding Macaronesia) appear to grow exclusively on hosts of the $U$. florida/subfloridana group. Samples from other geographical regions are however more diverse regarding host selection, and we expect many more host species to occur when more non-European specimens have been sequenced.

Distribution: Known from Austria, the Azores, Canada, the Canary Islands, Madeira, Sweden, and the U.K. 


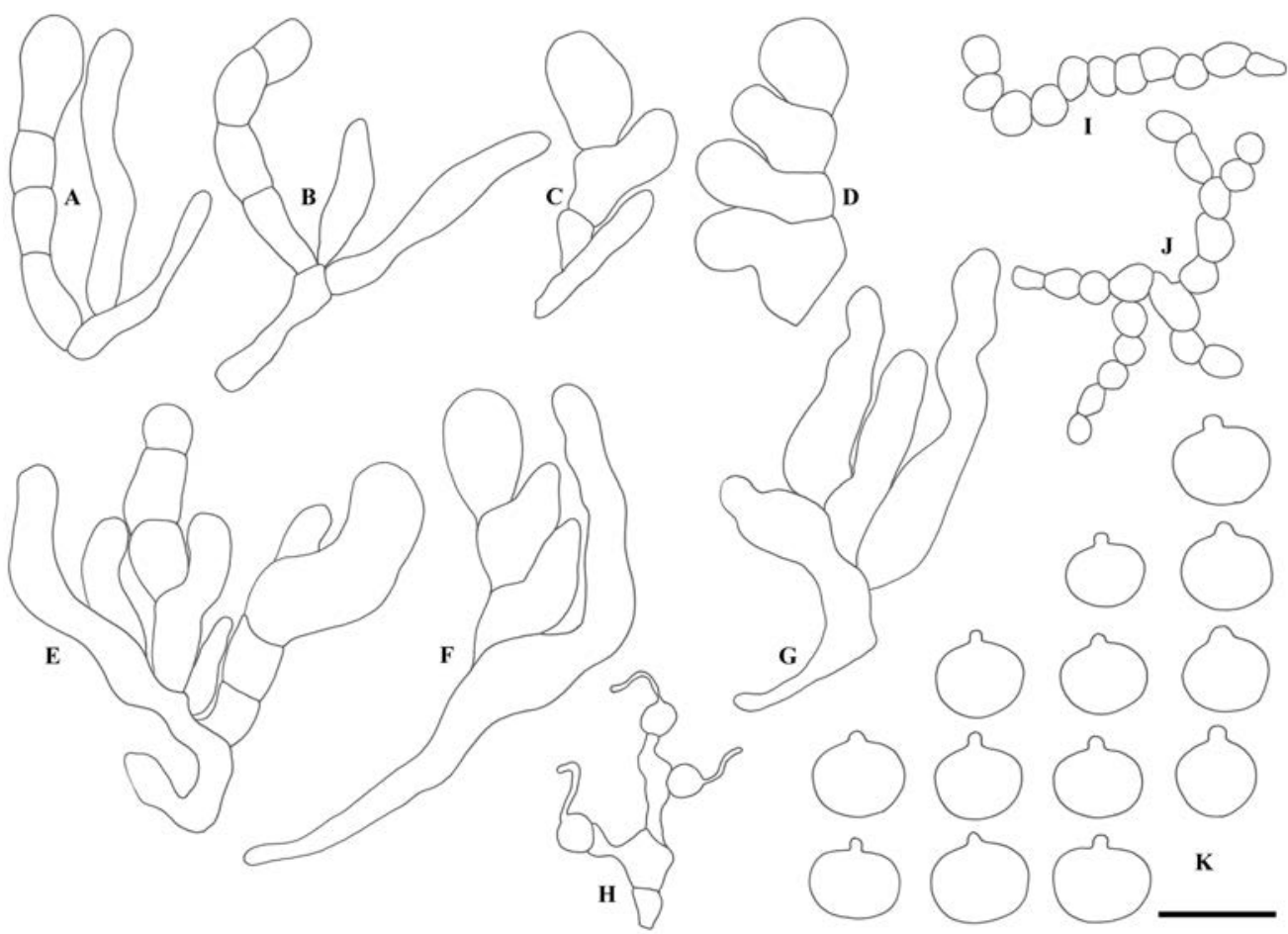

Fig. 8: Biatoropsis usnearum s.str. A-G - Development of basidia. H - Hyphae with haustorial branches. I-J Catenulate conidia. K - Basidiospores. [A-E: Millanes 507; F-K: Björk 14689]. - Scale $=10 \mu \mathrm{m}$.

Notes: The description above refers to Biatoropsis usnearum s. str. and is based on the descriptions by Diederich \& Christiansen (1994) and Diederich (1996), with a few modifications based on recently studied material, and on the exclusion of the newly described species. The circumscription of Biatoropsis usnearum s. str. will still need to be modified in the future when there is a better knowledge of the whole species complex. It is remarkable that both Biatoropsis hafellneri and Biatoropsis usnearum s. str., which are closely related to each other, share the presence of a basal clamp at the base of young basidia. This character had previously been overlooked in Biatoropsis and should be carefully checked in future morphological studies.

Additional specimens examined (on Usnea sp., unless specified): Austria. Steiermark, Steirisches Randgebirge, $47^{\circ} 24.08^{\prime} \mathrm{N}, 15^{\circ} 32.08^{\prime} \mathrm{E}$, on $U$. cf. florida, 24.X.1999, J. Hafellner s.n. (GZU 02-99). - Azores. Pico, between Lajes do Pico and Sao Roque do Pico, Bosque da Junqueira, $3^{\circ} 27.93^{\prime} \mathrm{N}, 28^{\circ} 17.95^{\prime} \mathrm{W}$, on U. macaronesica, 26.VII.2010, P. Diederich 17087a (S F264684); Pico, S of Sao Roque do Pico, $38^{\circ} 29.9^{\prime} \mathrm{N}, 28^{\circ} 18.58^{\prime} \mathrm{W}$, on U. macaronesica, 24.VI.2010, P. Diederich 17058 (S F264685, hb. Diederich). - Canada. Alberta, Boreal Plains, on U. glabrescens, 22.VII.2006, T. Goward s.n. (UBC); ibid., on U. glabrescens, 23.VI.2008, T. Goward s.n (UBC). British Columbia, Homathko Valley, 51 ${ }^{\circ}$ 'N, 124 ${ }^{\circ} 58^{\prime} \mathrm{W}$, on Usnea sp., 11.VIII.2007, C. Björk 14689 (UBC). - Canary Islands. La Palma, El Paso, Refugio El Pilar, 28³6'N/1750'W, 1452 m, VIII.2009, G. Amo s.n. (MAF-Lich). Madeira. S of Santana, West of Casa de Abrigo das Queimadas, along Levada do Caldeirão Verde, $32^{\circ} 47.09^{\prime} \mathrm{N}$, $16^{\circ} 54.49^{\prime} \mathrm{W}$, on $U$. cf. krogiana, 28.VIII.2014, P. Diederich 17778 (hb. Diederich); Rabaçal, along Levada das

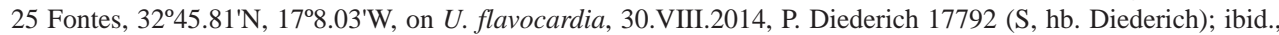
on U. fragilescens, 17794 (S F29146). - Sweden. Småland, Kalmar, Hallingeberg par., Borgberget, c. $2.6 \mathrm{~km} \mathrm{~S}$ of Ankarsrum church, $5^{\circ} 40.65^{\prime} \mathrm{N}, 1^{\circ} 20.45^{\prime} \mathrm{E}$, on U. subfloridana, 3.X.2009, M. Westberg 09-674 (S F264680), M. Westberg 09-676 (S F264681); ibid., on U. florida, M. Westberg 09-675 (S F264682). - U.K. Scotland, East Lothian (v.c. 82), on U. subfloridana, 6.VII.2008, B. Coppins s.n. (S F102407); West Ross, Duirinish, west side of Port Bàn, on Usnea cf. florida, 25.VII.2010, A. Millanes 507 (S F291462); West Ross, Loch Carron, Glen Attadale, North side of River Attadale, west of Strathan, on Usnea subfloridana, 27.VII.2010, M. Westberg s.n. (S F219463). 

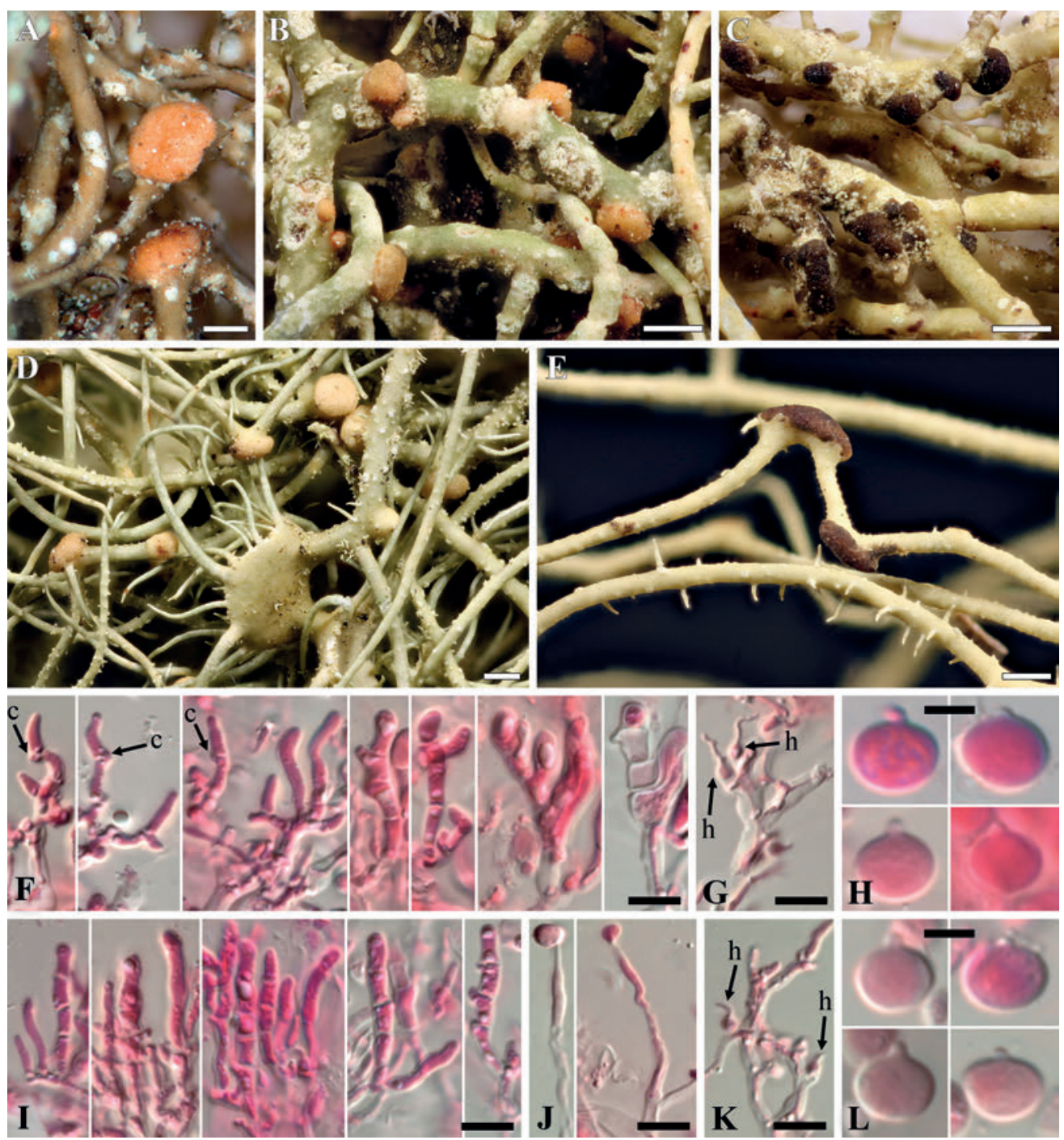

Fig. 9: Biatoropsis usnearum s.str. A-E - Basidiomata on the thallus of Usnea spp. [A, D, on U. subfloridana; B-C, on U. flavocardia; E, on Usnea sp.]. F, I - Probasidia with basal clamps (c) and mature basidia. G, K - Haustorial branches (h). J - Epibasidia with basidiospores. H, L - Basidiospores. [A: Räsänen s.n. (lectotype); B-C: Amo s.n.; D, I-L: Millanes 507; E, F-H: Björk 14689]. - Scales: A = $200 \mu \mathrm{m}$; B-E = $500 \mu \mathrm{m} ; \mathrm{F}-\mathrm{G}, \mathrm{I}-\mathrm{K}=10 \mu \mathrm{m} ; \mathrm{H}, \mathrm{L}=5 \mu \mathrm{m}$.

\section{Biatoropsis sp. F}

(Fig. 10)

Description: Basidiomata inducing the formation of convex, basally constricted galls, sometimes tuberculate with a central depression when mature, waxy gelatinous when wet, pale brown to dark brown or black, often with a reddish tinge, sometimes bright orange, $0.18-2.2 \mathrm{~mm}$ diam. Context hyphae thin-walled, $2-3 \mu \mathrm{m}$ diam. clamp connections not observed. Haustorial branches frequent, mother cell spherical to subspherical, $(2-) 3-4 \times 2-3 \mu \mathrm{m}$, haustorial filament $1 \mu \mathrm{m}$ diam., up to $10 \mu \mathrm{m}$ long. Hymenium hyaline, containing numerous probasidia; probasidial initials clavate, occasionally with a basal clamp. Basidia, when mature, 4-celled, with three transverse septa, often constricted at the septa, the lower cell with an attenuated stalk-like base, often longer than the upper cells, $21-72 \times 4-10 \mu \mathrm{m}$ 
(incl. stalk-like base, excl. epibasidia), lower part of the stalk-like base $2-4 \mu \mathrm{m}$ diam. Basidiospores globose to subglobose, $(4-) 5-8 \times(5.5-) 6-9(-11) \mu \mathrm{m}, \mathrm{Q}=0.6-1$, with a distinct apiculus, c. $1 \mu \mathrm{m}$ diam. Asexual morph: Catenulate hyaline conidia, individual conidia 2-6 $\times 2-4 \mu \mathrm{m}$.

Ecology and hosts: Lichenicolous on Usnea spp., including U. ceratina, U. exasperata s. l., U. hirta and $U$. rubicunda (thallus).

Distribution: Known from France, New Zealand, Papua New Guinea, Seychelles, and the U.S.A.

Notes: This species corresponds to clade 'F' distinguished by MiLlanes et al. (2014b) using multigene analyses, which is also recovered in this study (Fig. 1). Although Biatoropsis sp. F clearly constitu-
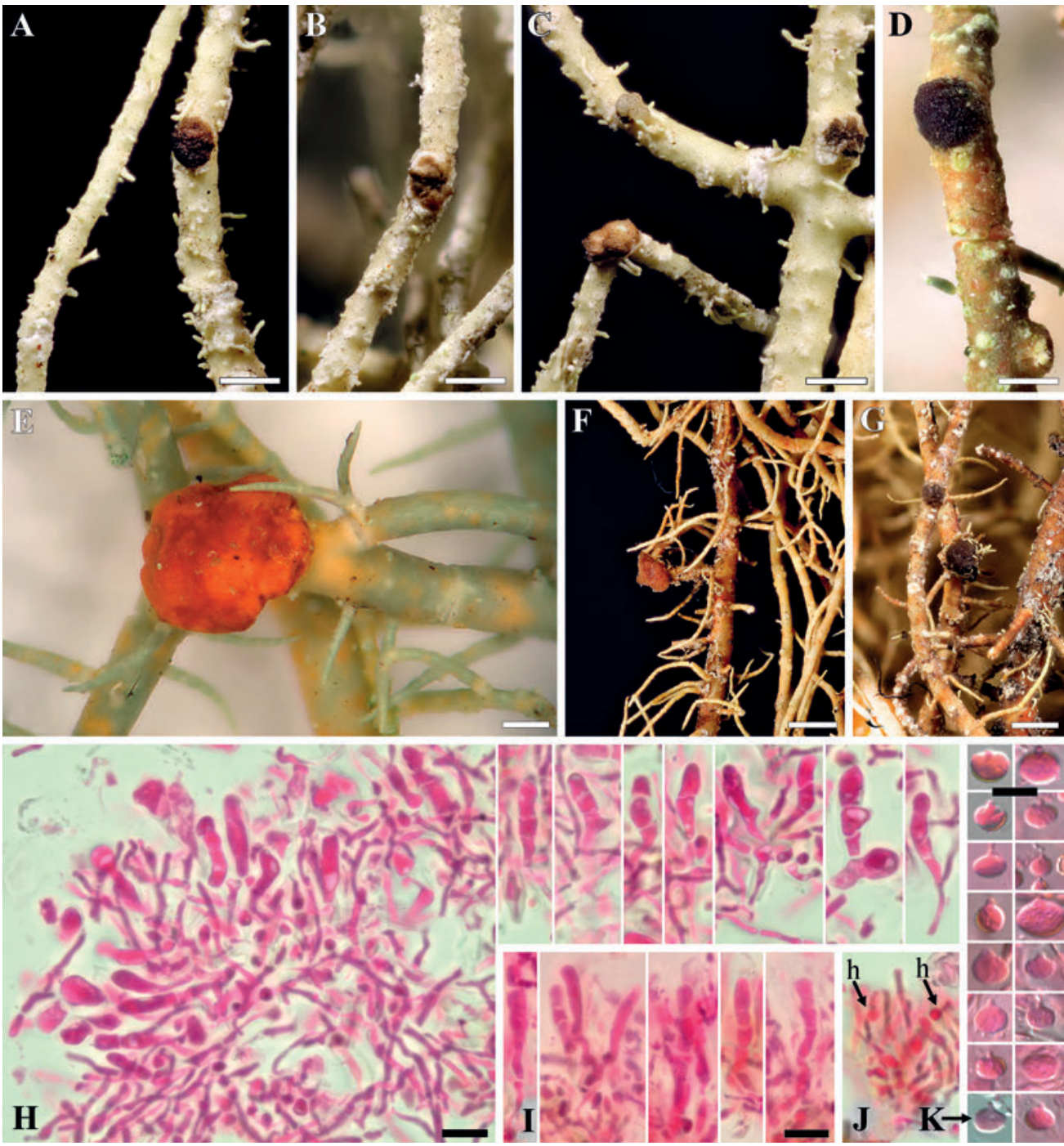

Fig. 10: Biatoropsis sp. 'F'. A-G - Basidiomata on the thallus of Usnea spp. A-C - On U. exasperata s. lat.. D-G On U. rubicunda. H-I - Hymenium and basidia. J - Haustorial branches (h). K - Basidiospores. [A-C, H: Diederich 18087B; D, K: Diederich 18149; E: Wedin 9429; F-G, I-J: Diederich 10800]. - Scales: A-D = $500 \mu \mathrm{m} ; \mathrm{E}=200 \mu \mathrm{m}$; $\mathrm{F}-\mathrm{G}=1 \mathrm{~mm} ; \mathrm{H}-\mathrm{K}=10 \mu \mathrm{m}$. 
tes an independent evolving lineage based on our molecular results, we have not been able to identify any morphological or ecological characters that could clearly distinguish specimens in this clade from Biatoropsis usnearum s. str. We thus wait with the formal description of this taxon, until more material allow us to get a better understanding of its morphology and ecology.

Specimens examined: France. Pyrenées-Atlantiques, $15 \mathrm{~km}$ SSE of Saint-Jean-de-Luz, S of Sare, forêt communale de Sare, along road D306 to col de Lizarrieta, on Usnea rubicunda, 26.VIII.2015, P. Diederich 18149 (hb. Diederich). - New Zealand. North Island, Rotorua, Lake Tarawera, north coast, $1 \mathrm{~km}$ E of Humphreys Bay, 13.XI.2001, F. Berger 16609 (S F92784, hb. Berger); Wellington, ca. $25 \mathrm{~km} \mathrm{~N}$ Masterton, 4043.23'S, $175^{\circ} 38.4^{\prime} \mathrm{E}$, on U. rubicunda, 28.XII.2010, M. Wedin 9429 (S F181399). - Papua New Guinea. Madang Province, Huon Peninsula, Finisterre range, Yupna valley, Teptep village, 5057'S, 146 ${ }^{\circ} 33^{\prime} \mathrm{E}$, on U. rubicunda, 30.VII.1992, P. Diederich 10800 (hb. Diederich). - Seychelles. Praslin, Praslin National Park, SE of Vallée de Mai, along trail to Glacis Noir and fire tower, $4^{\circ} 20.23^{\prime}$ S, $55^{\circ} 44.58^{\prime}$ E, on U. exasperata s. l., 5.VIII.2015, Diederich 18087B (S, SEY, hb. Diederich). - U.S.A. Arizona, Cochise Co., Chiricahua Mountains, lower portion of Morse Canyon, $31^{\circ} 51^{\prime} \mathrm{N}$, 109¹9.5'W, on U. hirta, 3.IX.1983, T. H. Nash III 20992 (ASU); Pima Co., road to Mount Lemon, NE of Tucson, $32^{\circ} 25^{\prime} \mathrm{N}, 110^{\circ} 43^{\prime} \mathrm{W}$, on U. hirta, III.1985, B. D. Ryan 12533 (ASU); Gila County, Tonto National Forest, Col. Devin

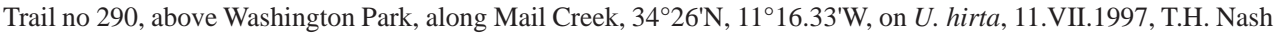
39494 (ASU, S F102404). California, Mendocino Co., Sky Trail, on U. ceratina, 11.VII.2008, Kocourková s.n. (S F264679).

\section{Acknowledgments}

We thank the curators of the herbaria that sent material on loan, and G. Amo de Paz, G. Aragón, F. Berger, C. Björk, B. Coppins, P. K. Divakar, T. Goward, J. Hafellner, R. Haugan, J.T. Klepsland, J. Kocourková, S. Merinero, S. PérezOrtega, and E. Timdal who kindly provided specimens for the present study. P. Clerc is thanked for identifying Usnea material. The Laboratory of Molecular Systematics at the Swedish Museum of Natural History in general and Bodil Cronholm in particular are warmly thanked for excellent technical support. P. Diederich thanks the Seychelles National Parks Authority for a collecting permit, and the Ministry of Environment, Energy and Climate Change and the Ministry of Tourism and Culture for an export permit of specimens collected in Republic of Seychelles. The research was supported by grants from The Swedish Taxonomy Initiative (STI 2016-27 4.3) to M. Wedin, the Spanish Ministry of Economy and Competitiveness (CGL2012-40123) to A. Millanes and M. Wedin, and the SYNTHESYS project SE-TAF 354 to A. Millanes.

\section{References}

Ariyawansa, H. A., Hyde, K. D. et al. (130 authors). 2015. Fungal diversity notes 111-252 - taxonomic and phylogenetic contributions to fungal taxa. - Fungal Diversity 75: 27-274.

Castresana, J. 2000. Selection of conserved blocks from multiple alignments for their use in phylogenetic analysis. - Molecular Biology and Evolution 17: 540-552.

CLERC, P. 1987. Systematics of the Usnea fragilescens aggregate and its distribution in Scandinavia. - Nordic Journal of Botany 7: 479-495.

DiedERICH, P. 1986. Lichenicolous fungi from the Grand Duchy of Luxembourg and surrounding areas. - Lejeunia n. S. 119: 1-26.

Diederich, P. 1990. Observations on new lichenicolous Basidiomycetes and Deuteromycetes. - In: Reisinger, A. \& Bresinsky, A. (eds). Fourth International Mycological Congress, IMC 4, Regensburg, Germany (F.R.G.), Abstracts: P. 15. - Regensburg: University of Regensburg.

Diederich, P. 1996. The lichenicolous heterobasidiomycetes. - Bibliotheca Lichenologica 61: 1-198.

Diederich, P. 2003. New species and new records of American lichenicolous fungi. - Herzogia 16: 41-90.

Diederich, P. 2007. New or interesting lichenicolous heterobasidiomycetes. - Opuscula Philolichenum 4: 11-22.

Diederich, P. \& Christiansen, M. S. 1994. Biatoropsis usnearum Räsänen, and other heterobasidiomycetes on Usnea. - The Lichenologist 26: 47-66.

Diederich, P. \& Marson, G. 1988. Tremella coppinsii, a new lichenicolous basidiomycete from Sarawak. - Notes from the Royal Botanic Garden Edinburgh 45: 175-176.

Diederich, P., Millanes, A. M. \& Wedin, M. 2014. Tremella umbilicariae (Tremellomycetes, Basidiomycota), a new lichenicolous species on Umbilicaria from Peru. - Bulletin de la Société des Naturalistes Luxembourgeois 115: $167-172$.

GaRDES, M. \& BRUNS, T. D. 1993. ITS primers with enhanced specificity for basidiomycetes: application to the identification of mycorrhizae and rusts. - Molecular Ecology 2: 113-118. 
Guindon, S. \& Gascuel, O. 2003. A simple, fast, and accurate algorithm to estimate large phylogenies by maximum likelihood. - Systematic Biology 52: 696-704.

KAтон, K. \& Tон, H. 2008a. Improved accuracy of multiple ncRNA alignment by incorporating structural information into a MAFFT-based framework. - BMC Bioinformatics 9: 212.

KATOH, K. \& TоH, H. 2008b. Recent developments in the MAFFT multiple sequence alignment program. - Briefings in Bioinformatics 9: 286-298.

Katoh, K., Misawa, K., Kuma, K. \& Miyata, T. 2002. MAFFT: a novel method for rapid multiple sequence alignment based on fast Fourier transform. - Nucleic Acids Research 30: 3059-3066.

Millanes, A. M., Diederich, P., Ekman, S. \& Wedin, M. 2011. Phylogeny and character evolution in the jelly fungi (Tremellomycetes, Basidiomycota, Fungi). - Molecular Phylogenetics and Evolution 61: 12-28.

Millanes, A. M., Westberg, M., Wedin, M. \& Diederich, P. 2012. Tremella diploschistina (Tremellomycetes, Basidiomycota, Fungi), a new lichenicolous species growing on Diploschistes. - The Lichenologist 44: 321-332.

Millanes, A.M., Diederich, P., Westberg, M., Knutsson, T. \& Wedin, M. 2014a. Tremella rhizocarpicola sp. nov. and other interesting lichenicolous Tremellales and Filobasidiales in the Nordic countries. - Mycokeys 8: 31-41.

Millanes, A.M., Truong, C., Westberg, M., Diederich, P. \& Wedin, M. 2014b. Host switching promotes diversity in host-specialized mycoparasitic fungi: uncoupled evolution in the Biatoropsis-Usnea system. - Evolution 68: 1576-1593.

Millanes, A.M., Diederich, P., Westberg, M., Pippola, E., \& Wedin, M. 2015. Tremella cetrariellae (Tremellales, Basidiomycota, Fungi), a new lichenicolous fungus on Cetrariella delisei. - The Lichenologist 47: 359-368.

PosAdA, D. 2008. jModelTest: phylogenetic model averaging. - Molecular Biology and Evolution 25: 1253-1256.

RÄsÄNEN, V. 1939. Die Flechtenflora der nördlichen Küstengegend am Laatokka-See. - Annales Botanici Societatis Zoologicae-Botanicae Fennicae Vanamo 12: 1-240.

Ronquist, F., Teslenko, M., van der Mark, P., Ayres,D. L., Darling, A., Höhna, S., Larget, B., Liu, L., Suchard, M. A. \& Huelsenbeck, J. P. 2012. MrBayes 3.2: efficient Bayesian phylogenetic inference and model choice across a large model space. - Systematic Biology 61: 1-4.

Sérusiaux, E., Diederich, P., Ertz, D. \& van den Boom, P. 2003. New or interesting lichens and lichenicolous fungi from Belgium, Luxembourg and northern France. IX. - Lejeunia n. S. 173: 1-48.

Silvestro, D. \& MichalaK, I. 2012. RaxmlGUi: a graphical front-end for RAxML. - Organisms Diversity \& Evolution 12: 335-337.

Stamatakis, A. 2006. RAxML-VI-HPC: maximum likelihood-based phylogenetic analyses with thousands of taxa and mixed models. - Bioinformatics 22: 2688-2690.

Zamora, J. C., Pérez-Ortega, S. \& Rico, V. J. 2011. Tremella macrobasidiata (Basidiomycota, Tremellales), a new lichenicolous fungus from the Iberian Peninsula. - The Lichenologist 43: 407-415.

Zamora, J. C., Millanes, A. M.,Wedin, M., Rico, V. J. \& Pérez-Ortega, S. 2016. Understanding lichenicolous heterobasidiomycetes: new taxa and reproductive innovations in Tremella s. l. - Mycologia 108: 381-396.

Manuscript accepted: 30 June 2016.

Communicated by: Lucia Muggia

\section{Addresses of the authors}

Ana M. Millanes, Universidad Rey Juan Carlos, Departamento de Biología y Geología, Física y Química Inorgánica, Móstoles, Tulipán s/n, 28933, Móstoles, Spain.

E-mail: ana.millanes@urjc.es

Paul Diederich, Musée national d’histoire naturelle, 25 rue Munster, 2160 Luxembourg, Luxembourg. E-mail: paul.diederich@education.lu

Martin Westberg, Uppsala University, Museum of Evolution, Norbyvägen 16, 75236 Uppsala, Sweden. E-mail: martin.westberg@em.uu.se

Mats Wedin, Swedish Museum of Natural History, Department of Botany, PO Box 50007, 104 05 Stockholm, Sweden. E-mail: mats.wedin@nrm.se 